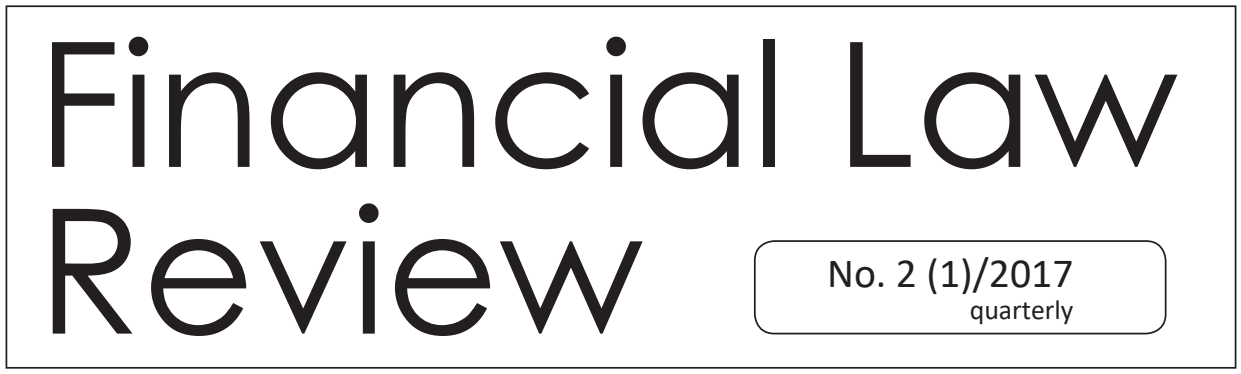

UNIVERSITY OF GDAŃSK • FACULTY OF LAW AND ADMINISTRATION

http://www.ejournals.eu • http://czasopisma.bg.ug.edu.pl

\title{
RUSSIAN TAX LEGISLATION AND STANDARDS OF INTERNATIONAL LAW: CORRELATION, PROBLEMS OF LAW ENFORCEMENT AND DIRECTIONS OF PERFECTION ${ }^{1}$
}

\section{Nadezhda Baliuk}

\section{Annotation}

This article is devoted to a question of correlation of national and international tax law. An effort to cover the most widespread in Russian doctrine theoretical ideas about nature and subject of international tax law is undertaken. The author cites his own vision of mentioned theoretical problems, and also formulates reference direction, on which development of standards of international tax law is effected, defines the limits of international and Russian internal tax law and considers their correlation, problem aspects of law enforcements.

Existence and interaction of two systems of law - national and international inevitably create theoretical and utilitarian questions about the character of such

\footnotetext{
1 The article is a reprint of the article originally published in System prawnofinansowy: prawo finansowe wobec wyzwan XXI wieku. Law and finance: the financial law towards challenges of the XXI century / J. Gliniecka (red.), CeDeWu, Warszawa 2013
} 
interaction, about correlation of sub-national and international rules of law. Questions of such nature appear on common level, with regard to interaction of two law systems in whole, and on the level of sectoral systems interaction. Sweepingly elapsing processes of globalization conditioned expansion of sphere of states and other subjects of international law interrelation. The taxation takes part in such spheres of interrelations. Processes of economical integration of sovereign states at each others economics, extension of "a foreign component" in fiscal legal relationship arouse the necessity of international collaboration. These circumstances led to the formation of international tax law.

Prior to considering the correlation of Russian tax legislation and standards of international law, let's appeal to important theoretical question: can we speak about existence of international tax law? In Russian jurisprudence the predominant opinion is, that international tax law is an absolutely independent branch (segment of branch) of international law, but researchers restrict its subject sphere in different ways. Thus, I.I. Kucherov considers, that subject of this element of international law unites relations between states concerning concluding of international tax treaties for the purpose of tax jurisdiction differentiation of states; tax treatment between states and natural and juridical persons of other states (subjects of foreign law), that is tax relations dealing with sovereignty of other states; relations of public character between juridical and(or) natural persons of different states, arising, for example, withholding by fiscal agent a tax from a foreign person with source of disbursement ${ }^{2}$.

V.A. Kashin writes, that in tax law of any country two parts can be sorted out: the first one regulates relationship completely falling under national jurisdiction of country; the second one regulates relationship, in which foreign component takes part; although the second part is named international law ${ }^{3}$. We consider, that this definition of a subject of international tax law is too wide, that does not allow to draw an accurate line of demarcation between tax standards of two systems of law. The fact of the matter is, that tax legal relationship with participation of "foreign element" can be regulated solely by norms of sub-national tax legislation, and in such cases, we can't speak about application of norms of international legal character, because norms of territorial law are created independently by sovereign state in law-making bodies unilaterally, without other subjects of international

\footnotetext{
2 Kucherov I.I. Theoretical questions of international tax law and it's place in a system of tax-legal regulation/I.I. Kucherov //Financial law. - №1.-2006.p.45

${ }^{3}$ Kashin V.A. Tax agreements of Russia. International tax planning for business/ V.A. Kashin. - M.: Finances, 1998.p.49.
} 
character. An example of such situation is norm of paragraph 1 of article 275 of Tax Code of the Russian Federation, according to which taxpayers, getting dividends from foreign organization through permanent representation of foreign organization in the Russian Federation, are not able to abate the amount of tax, calculated under present paragraph, worth of amount of tax, calculated and paid according to the place of location of the source of revenue, unless other facts are specified by the international treaty. The absence of international treaty means invocation of this sub-national rule to relationship with foreign element.

In general, extremely broad definitions of the subject of the international tax law in Russian doctrine are widespread. I.A. Laryutina considers that standards of the international tax law regulate not only international relationship, but also international relationship of non-governmental character, with subjects of national law of different states as their participants ${ }^{4}$.

There are also extremely special opinions, denying the existence of international tax law itself. Particularly, R.A. Shepenko has such an opinion, following G. Ellinek, who considers, that international law can't regulate relationship between "authority and subordination", because it is law between subjects equal in rights, and tax law is relationship between authority and property ${ }^{5}$. But we can't agree with such an opinion. Really, tax treatments are formed between unequal subjects. But states, matching their will according to the questions in the sphere of taxation, don't report and dominate, but absolutely freely and designedly limit their fiscal sovereignty as an effective problem-solving of taxation. Any international treaty is an act of self-restraint of state's sovereignty; it is the basis of all international judicial intercourse. If one takes into account that, majority of international treaties are passing in sphere of so-called public law; and sub-national characteristic of public law is indication of subordinated relationship; then, R.A. Shapenko's facts bring to the negation of considerable sphere of international law. From our point of view, international treaties, concluded by states in sphere of tax law, are free from references of sub-national law (relationship between "authority and subordination"). International tax law is based on the principle of voluntary limit of fiscal state's sovereignty and act as relationship of co-ordination, but not as relationship of subordination.

\footnotetext{
${ }^{4}$ Laryutina I.A. International tax law/I.A. Laryutina//Moscow journal of international law.-№4. - 2001.p.107-108.

5 Shepenko R.A. On the issue of international tax law./ R/A/ Shepenko//The Modern Problems of Tax Law Theory: materials of international scientific conference. Voronezh, September 4-6, 2007/ ed. M.V. Karaseva. - Voronezh.: Publishing house of Voronezh State University, 2007.p.486.
} 
Extension of "a foreign component" in tax treatment does not allow to affirm, that such relationship are regulated by standards of the international tax law. From our point of view, signs of belonging of specific provision to this structural formation are: 1) presence of such an element as relationship between states and intergovernmental organizations; 2) these relationship are formed on the terms of taxation. That is, from our point of view, exactly the presence of mutual communication between sovereign states or between sovereign state and state with transnational international organization is the evidence of international character, framed in the course of such communication of standard, but not the other signs (such as foreign component, for example). The basic source of standard of international tax law is international treaty accepted according to the treatment of taxation.

Thus, presence of the international tax law inevitably creates condition of interaction with the national tax law. Frequently, international legal standards are not directed for immediate regulation of tax relationship; they represent certain general provisions, which are to be realized in internal legislation. For example, member-countries of Agreement, concluded between Governments of member-countries of Communities of Independent States, about concerted principals of tax policy (Moscow, March13, 1993), charged themselves to follow concerted tax policy on the basis of principals of unification and regulations of taxation. This agreement does not contain direct standards regulating tax relationship, but it allocates designated principles and proposes discharge of international liability through internal tax legislation activity.

The correlation of standards of national and international legislation is formed differently in the law of different countries. In some countries, there is no priority of international treaty on constitutional level, and such agreements are incorporated into legislation of a state and acquire the status equal to legal texts (FRG, Great Britain) ${ }^{6}$. In Russia, according to paragraph 4 of article 15 of the Constitution, generally recognized principles and standards of international law and international treaties of the Russian Federation are constituent of its legal system, in case of establishing of other standards by international treaty of the Russian Federation standards of international treaty are applied. This disposition is realized on the level of sectoral legislation: article 7 of the Tax Code of the Russian Federation read as follows - in case of establishing of other rules and standards of international treaty of the Russian Federation, concerning taxation and tallage, different rules and standards are established, than required hereby Code and normative legal

${ }^{6}$ Kucherov I.I., provided work,p.47 
texts about taxes-and-duties, that rules and standards of the international treaties of the Russian Federation are used.

International tax legislation is forms in the following lines:

1) orientation of unification and harmonization of internal tax legislation of states. These processes are provoked by necessity of states, which are constituent of different international associations, to adjust national tax legislation in accordance with certain general requirements. Russia is a participant of processes of unification and harmonization of tax legislation with legislation of other countries. In this article, the Agreement has been already mentioned, which was concluded between Governments of member-countries of CIS, about concerted principals of tax policy (Moscow, March 13, 1993), created commitment of implementation of concerted tax law on the basis of unification of standards and rules of taxation, application of single specification of basic tax, concerned the interests of all states in CIS's membership, to ensure interest in investment and other forms of financial and economic activities on its territory (article 2 of the Agreement).

Within the bounds of activity of Eurasian Economic Community (EurAsEC) the Decision of Integration Committee of Eurasian Economic Community № 75 “About basic principles of harmonization of tax administration in member countries of EurAsEC (Moscow, April 5, 2002) was carried, in which The basic principles of such harmonization were established and specific directions of international cooperation were formed;

2) orientation, connected with removal of double taxation. Double taxation represents the situation, when one and the same taxpayer, by act of law of more the one states, is to pay the tax from the same object for the same tax period. For example, situation of double taxation in relation to individual and juridical persons can arise for the reason that, they can be recognized tax residents in several countries, because there are different criteria of detection of residency in internal tax legislation of different countries (criterion of the place of registration or criterion of place of business). It is fairly to note, that such situation brings to negative consequences, among which E.S. Merkulov marks out sag of foreign-economic activity of subjects of national law, leading to minimization of product exchange, services between states and reduction of motion of manpower resources and investments ${ }^{7}$. States, realizing such consequences, are striving for solution of the problem of double taxation through the making

7 Merculov E.S. Conception and subject of international tax law: moot cases/ E.S. Merculov// Law and politics.-№4.- 2004.p. 94. 
of international treaty. In praesenti Russia is the participant of treaties in order to avoid a double taxation with Indonesia, Israel, Sri Lanka, Greece, Mexico, Austria, Portugal, Norway, Finland, Ukraine and other countries. During the completion of international treaties in order to avoid a double taxation, the model agreement, accepted by Governmental Regulation of the Russian Federation (May 28,1992) № 352 "About the completion of international treaties in order to avoid a double taxation of revenue and property". Regulation of article 323of the Tax Code of the Russian Federation provides for actually paid by taxpayer, constituted tax resident of the Russian Federation, beyond the territory of the Russian Federation in compliance with legislation of other countries, of amount of income tax, received beyond the territory of the Russian Federation, are not taking into account of discharge of tax in the Russian Federation, if other situations are provided by treaty (agreement) in order to avoid a double taxation. In this case standards of internal legislation refer to standards of international treaties;

3) orientation connected with question of co-operation and mutual aid re observance of tax legislation. These international treaties allow to co-ordinate efforts of states for the suppression of tax felonies and information interchange about tax legislation. Russia is a participant of such treaties with Uzbekistan and Bulgaria, and beside that takes part in multilateral agreement of member-countries of CIS about mutual aid re compliance of tax legislation and struggle with breaches in this sphere;

4) orientation, connected with solution of problems of taxation between Russia and other countries. Particularly, by the Agreement between Government of the Russian Federation and Government of the Republic of Kazakhstan about concerted principles of calculation and discharge of value-added tax of March,23 1992;

5) orientation, connected with concession of a right to tax immunities and tax privileges. Such privileges and immunities are giving to certain categories of taxpayers non-residents of Russian Federation in concordance with standards of international treaties, customs and principal of mutual comity. Thus, in concordance with Vienna Convention on Diplomatic Relations (Vienna, April 18, 1961), sending state and incumbent of mission are released from all national, community and county taxes, dues and tolls in point to governmental premises, hired and own, except such taxes, dues and tolls, which are corresponded as pay for certain servicing types. Tax immunities and privileges are 
afforded to consular offices and their staff for the reason of Vienna Convention on Consular Relations (Vienna, April 24, 1963).

Thus, we produced reference direction of forming of international tax legislation and in forming of which the Russian Federation takes part. It should be noted, that standards of the international tax law are not directed to certain regulation of internal tax legal relationship - this is patrimony of the national legislator. Such standards create international legal obligations on matching of internal tax legislation with formed demands, and government, as sovereign participant of international-legal collaboration, committed such liabilities voluntary and in its own interests.

Not so long ago Russia joined the World Trade Organization - the President of the Russian Federation set his hand on the Federal statue "About ratification of the Protocol of accession of Russian Federation to Marrakesh Agreement Establishing the World Trade Organization April 15, 1994”. Joining the WTO will entail consequences of all sorts in sphere of taxation, particularly member-countries of such organization have an opportunity to exchange information on tax felonies in facilitated conditions, and taxation of Russian and foreign wares will be unified. This step, accomplished by Russian Federation, will entail major modifications in internal tax and tariff legislation, consequently, will give rise to a new wave of interest to the problem of correlation between sub-national and international tax legislation.

\section{List of references}

1. the Constitution of the Russian Federation, accepted by nation-wide-voting December 12, 1993. - Legal system "Consultant plus".

2. the Tax Code of the Russian Federation: the Federal law 31.07.1998 №146-Federal Law. - Legal system "Consultant plus".

3. Kashin V.A. Tax agreements of Russia. International tax planning for business/ V.A. Kashin. - Moscow.: Finances, 1998.page 49.

4. Kucherov I.I. Theoretical questions of international tax law and its place in a system of tax-legal regulation/I.I. Kucherov //Financial law. - №1.-2006.page 45

5. Laryutina I.A. International tax law/I.A. Laryutina//Moscow journal of international law.-№4.- 2001.pages 107-108.

6. Merculov E.S. Conception and subject of international tax law: moot cases/ E.S. Merculov// Law and politics.-№4.- 2004.page 94.

7. Shepenko R.A. On the issue of international tax law./ R/A/ Shepenko//The Modern Problems of Tax Law Theory: materials of international scientific conference. Voronezh, September 4-6, 2007/ ed. M.V. Karaseva. - Voronezh.: Publishing house of Voronezh State University, 2007.page 486. 